\title{
Brachiopod populations: distribution in fjords of British Columbia (Canada) and tolerance of low oxygen concentrations
}

\author{
Verena Tunnicliffe, Kerry Wilson \\ Biology Department, University of Victoria, Victoria, British Columbia, Canada V8W 2Y2
}

\begin{abstract}
Brachiopods are not generally considered to be important components of modern communities, especially in comparison to their Paleozoic heyday. By using a submersible to examine the deep walls of 4 fjords in British Columbia (Canada), the abundance of 3 brachiopod species was documented. Laqueus californianus is ubiquitous from 50 to $700 \mathrm{~m}$ water depth being found in conditions of high turbulence, high suspended sediment load and low oxygen concentrations. Terebratulina unguicula is most common in a fjord that shows annual upwelling of anoxic waters; it is one of the few animals found in areas with oxygen levels frequently below $0.1 \mathrm{ml} \mathrm{l}^{-1}$. The inarticulate Crania californica has a restricted distribution that may be a function of low dispersability. Over a number of years, one monitored brachiopod population was stable although a gradual retreat from the low oxygen waters was observed. Size-frequency examinations of in situ brachiopods revealed no distinguishable size classes; the death assemblage resembled the in situ population but a dredged collection did not. Brachiopods are common in all British Columbian fjords; we measured an average density of $190 \mathrm{~m}^{-2}$ while maxima ranged up to $945 \mathrm{~m}^{-2}$. Bivalves, commonly cited as ecological replacements of brachiopods, are virtually absent. Two features of the brachiopods stand out: they withstand prolonged periods of low oxygen stress, and they remain a consistent part of the deep-water, hard-substratum habitat.
\end{abstract}

\section{INTRODUCTION}

Few modern invertebrate texts give much room to the Phylum Brachiopoda because of its 'minor' status in present-day habitats, especially in comparison with its Paleozoic prominence in subtidal marine communities. Nearly all recent studies on brachiopods are conducted with the object of enhancing paleointerpretations, and the group is rarely considered in the context of its contribution to Recent communities. Examination of an authority on brachiopod biology (Rudwick 1970) suggests major biological limitations: they are stenotypic, rarely tropical, excluded from the intertidal, deterred by high turbidity and rapid currents, and unlikely to tolerate low levels of dissolved oxygen. The decline of the Brachiopoda has elicited many causative scenarios, from adverse environmental conditions (Rudwick 1970), increased predation (Stanley 1974), competitive displacement (Thayer 1979), to lack of flexibility in reproductive development (Valentine \& Jablonski
1983). Speculations on their lack of success often suppose or imply an inferiority to the expanding bivalves.

Studies on extant brachiopods are gradually widening the known limits to brachiopod habitats. Where subtidal hard substrata are available to SCUBA divers, brachiopod populations are often found. However, many habitats so easily seen in fossiliferous, uplifted strata are unavailable for Recent study. There is little information on modern assemblages from 60 to $1000 \mathrm{~m}$ depth thus comparisons with ancient communities cannot be made easily. Our study was initiated when surveys of epifauna on vertical fjord walls in British Columbia revealed the ubiquitous presence of brachiopods. In addition, studies in a periodically anoxic basin found that brachiopods were among the few taxa surviving close to the anoxic interface (Tunnicliffe 1981). This study examines in detail the distribution and nature of brachiopod populations in several fjords 


\section{METHODS}

Study area. The British Columbia fjords are glaciercarved features with vertical walls of igneous or metamorphic rock. A common feature is a sill at the fjord mouth that may restrict water exchange. Four fjords were examined in this study (Fig. 1). Jervis Inlet, one of the deepest on the coast at $730 \mathrm{~m}$; it has clear, well-oxygenated, oligotrophic water. Knight Inlet with a maximum depth of $550 \mathrm{~m}$ receives a large influx of glacial melt-water resulting in heavy silt loads that decrease logarithmically down-inlet (Farrow et al. 1983); tidal exchange across the sill near the mouth is very turbulent (Farmer \& Smith 1980). The interconnected Dean and Burke Channels are treated together; maximum depth is $590 \mathrm{~m}$ and both are relatively well-flushed receiving a moderate sediment load. In the fourth fjord, Saanich Inlet on Vancouver
Island, a $70 \mathrm{~m}$ depth sill constrains exchange with the 230 m inner basin in most summers this water column develops a lower anoxic layer that is replaced from below as dense, oxygenated water flows over the sill each fall (Herlinveaux 1962, Anderson \& Devol 1973); this inflowing water moves into the bottom of the fjord pushing the low oxygen water upward.

Dissolved oxygen concentrations. Over 3 yr, 27 oxygen profiles were made in Saanich Inlet, 4 in Jervis Inlet, 7 in Knight Inlet, and 2 in Dean/Burke. Samples were obtained from either surface vessel bottle casts, or by drawing water through a hose on the submersible arm, into the sphere, and fixing it in situ. With this latter method, we sampled close to the brachiopods. Oxygen concentrations were measured by the Winkler method (Strickland \& Parsons 1972) modified to detect low oxygen levels.

Submersible observations. The data presented here

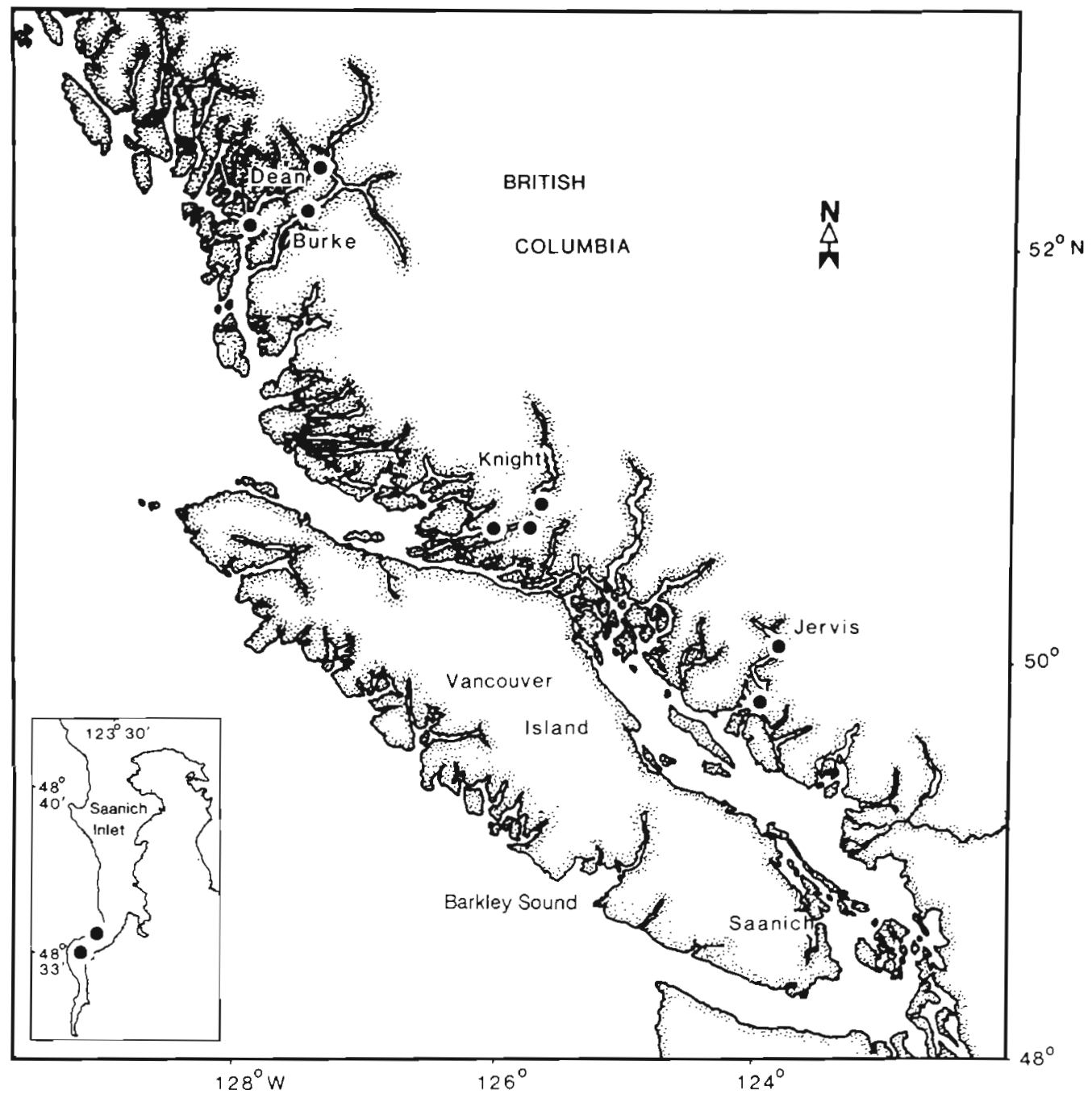

Fig. 1. Locations along the British Columbian coast where photographic data were collected. Each circle may represent many dives to obtain a complete transect. It is from the more southerly site in Saanich Inlet that the oxygen data in Fig. 4 come 
were gathered from photographs taken from the manned submersible 'Pisces IV' during 28 dives. Observations from another 15 dives supplement interpretations. During a dive, the submersible descended to the fjord floor, motored into the cliff, and ascended facing the wall at a distance of about $1 \mathrm{~m}$. In early dives, internal cameras were connected to an external strobe but later, photographs were taken with an external Photosea stereo camera from which $35 \mathrm{~mm}$ stereo slides resulted. For each photograph the submersible approached until an attached $30 \times 30 \mathrm{~cm}$ quadrat touched the wall (Fig. $2 \mathrm{~A}, \mathrm{~B})$. To aid replication of the Saanich Inlet transect, the top of a chain was bolted at $15 \mathrm{~m}$ depth and the bottom dropped to $115 \mathrm{~m}$. Some movement of the chain occurred over the years due to current and fishing snags. Observation difficulties included poor visibility at times in Saanich and Knight Inlets, poor cliff proximity at numerous depth intervals due to overhangs, nonvertical slopes that provided poor photographic surfaces, and the truncation of most dives at $40 \mathrm{~m}$ to avoid entanglement of the submersible on overhanging trees.

Collections. Despite the difficulty in collecting while suspended on a cliff, specimens were gathered to verify identifications in Saanich and Knight Inlets. In Jervis Inlet, the wall was dredged from 350 to $30 \mathrm{~m}$. In September 1982, brachiopod shells on a sedimented ledge in Saanich Inlet at $125 \mathrm{~m}$ were collected by a sub-held box core of about $10000 \mathrm{~cm}^{3}$. Specimens of all local species were examined in Royal British Columbia Museum collections.

Photographic analysis. All photographic slides from each dive were projected and selection for subsequent analysis was made using these criteria: (1) good image clarity and exposure, (2) acceptable contact between the quadrat or chain and the wall, (3) rock surface plane parallel to photograph plane (usually about 75 to 105 degree slope). Total number of photographs used for data collection was 379 out of the 1950 available.

Species identification from photographs is subject to error. Species were separated where little trouble in the identification was encountered, but for many Saanich photographs Terebratulina unguicula could not be distinguished from small Laqueus californianus with satisfactory certainty. The quadrat defined an area 30 by $30 \mathrm{~cm}$ which was about half of the photo area. Highest brachiopod densities were often seen on vertical surfaces; such an area would be used for the density count even if it meant redefining the quadrat area. Saanich Inlet images with the chain were viewed in stereo to determine which rock faces were in the same plane as the chain and the camera. Using the chain links as scale, an area of $30 \times 30 \mathrm{~cm}$ was then defined around the cleanest, vertical surface. This method was chosen because of the extreme heterogeneity of the substratum over which averaged brachiopod densities reflect the suitability of the substratum in the immediate area. By selecting $900 \mathrm{~cm}^{2}$ areas of vertical to overhanging surfaces which invariably had the highest densities we minimized substratum effects to compare depths and fjords. The net result is that our counts represent maximum density estimates. About $30 \%$ of the photographs had neither quadrat nor chain available to give scale. To avoid rejecting these clear photographs, we chose to make density estimates. The largest Laqueus californianus in each photograph was selected and its size estimated based on collections from that site. A $30 \times 30 \mathrm{~cm}$ area was defined around that individual and a count made. A check on this method on scaled photographs gave errors ranging from 0 to $15 \%$.

Brachiopod size measurements were made on only those images with excellent definition, a well-placed scale and good shell orientation; criteria were strict enough that only 60 photographs qualified with a total of 670 individuals. Slides were projected onto a digitizing tablet and sizes measured using Bioquant-II Image Analysis System operating on an Apple II-Plus microcomputer. Width of the brachiopod was usually measured although rarely shell length had to be used for Laqueus californianus for which, on collected specimens, length to width ratios were variable but centered on 1.0 .

\section{RESULTS}

Fig. 2 illustrates the contribution of brachiopods to the epibiota of fjords. The community is dominated by perennial suspension/filter feeders and below $45 \mathrm{~m}$, primary producers are rarely seen. Sponges (Demospongia and Hexactinellida) represent major spaceoccupiers. Solitary individuals with deterministic growth are otherwise most common: brachiopods, ascidians, serpulids, scleractinian corals, and anemones. Colonial animals such as gorgonian corals, ascidians, phoronids, and bryozoans are also represented.

\section{The brachiopod species}

This study investigated 2 articulate and 1 inarticulate brachiopod. The most common species was Laqueus californianus (Koch 1848) (Fam. Laqueidae) which showed a preference for vertical and overhanging surfaces where it attached by a short pedicle (Fig. 2A, C, D). There is some confusion concerning the status of a second Laqueus species apparently endemic to this area. L. californianus var. vancouveriensis was described by Davidson (1887) for specimens from Vancouver Island and Queen Charlotte Island areas and was reaffirmed as a subspecies by Dall (1920). In 1944 , 

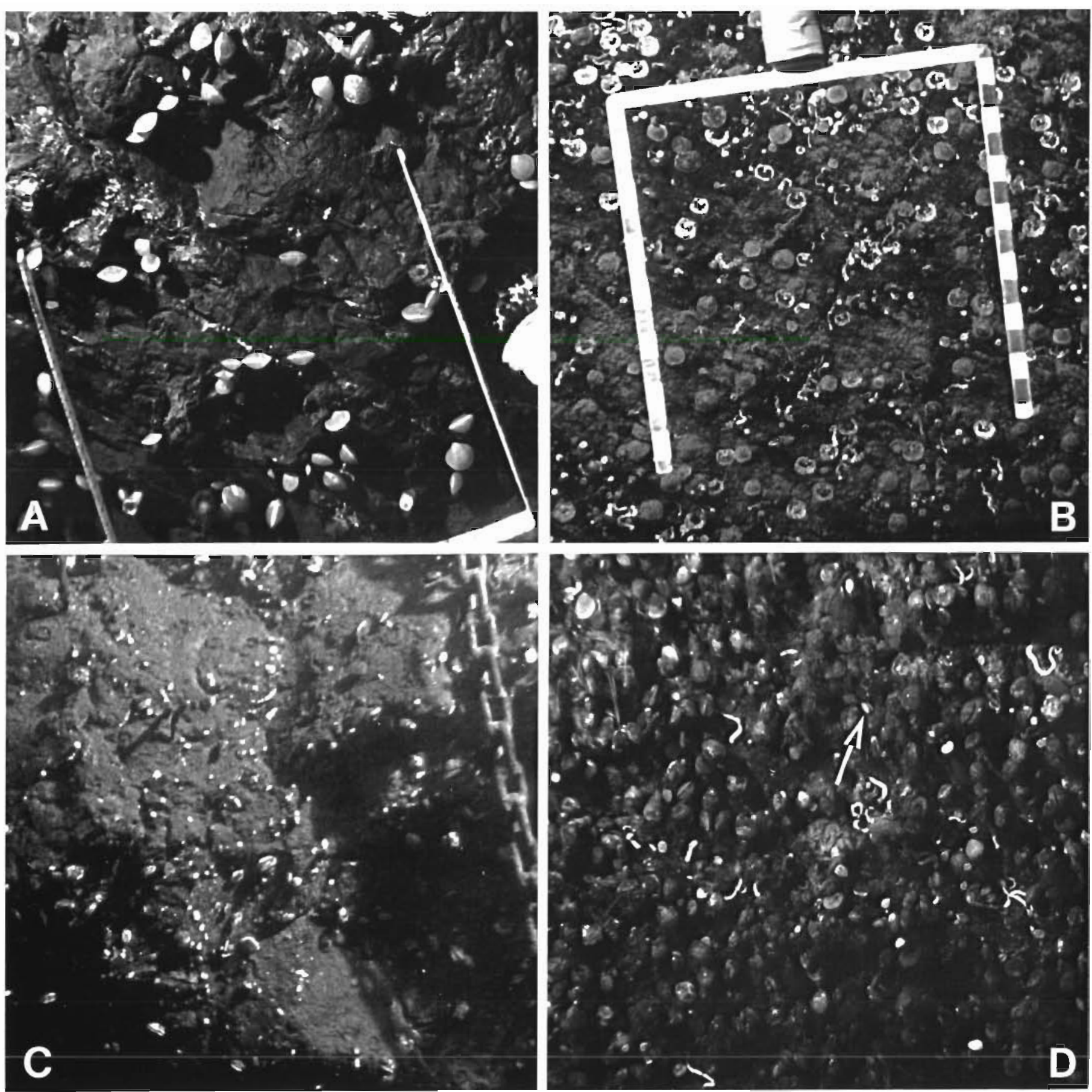

Fig. 2. Original photographs taken as colour transparencies from Pisces [V submersible. (A) Jervis Inlet at $420 \mathrm{~m}$; the vertica] wall is populated by Laqueus californianus; a glass sponge and a small coral can be seen to the right; scale: $30 \mathrm{~cm}$ on each side. (B) Dean/Burke Channel at $130 \mathrm{~m}$; the inarticulate brachiopod Crania californica cements to the wall by the brachial valve; serpulid polychaetes and 'scars' of C. californica can also be seen; scale: $30 \mathrm{~cm}$ a side (C) Saanich Inlet at $85 \mathrm{~m}$ where Terebratulina unguicula predominates; chain links measure 4.1 by $2.3 \mathrm{~cm}$ each. (D) High densities of brachiopods in Saanich Inlet. Larger individuals are $L$. californianus, smaller white ones (arrow) $I$ unguicula; serpulids, hydroids, anemones and ascidians are also 
Hertlein \& Grant elevated it to species status on the basis of a larger foramen and distinctly smaller shell.

After comparing our specimens with the figures in these communications and with large specimens from Cobb Seamount $\left(46^{\circ} 45^{\prime} \mathrm{N}, 130^{\circ} 40^{\prime} \mathrm{W}\right)$ and Barkley Sound (Fig. 1), we agree with Bernard's (1972) assessment that the local form should remain as a subspecies. While sizes do tend to be smaller, foramen shape, colour, and shell shape show wide variation. Mattox (1955) noted a distinct shift of size in his Santa Catalina specimens such that deeper Laqueus 'characters approach those of the questionable and more northern subspecies vancouveriensis' (p. 75). In most of the fjords studied, L. c. var. vancouveriensis showed little tendency for clumped growth but rather, settled singly on the substratum. Although Hertlein \& Grant (1944) cited this behaviour as support for separation of the species, L. C. var. vancouveriensis from Barkley Sound also showed settlement of juveniles upon adults as is common in southern L. californianus.

Terebratulina unguicula (Carpenter 1864) (Fam. Cancellothyrididae) is distinguished photographically by its creamy colour, sharp pedicle angle, and (sometimes) faint ribbing (Fig. 2c). The type locality for the species is off Vancouver Island and it has often been collected attached to stones and shells (Bernard 1972). Our largest specimens exceeded the measurements given by Davidson (1887) and Hertlein \& Grant (1944), but the diagnostic dichotomous ribs and margin crenulations were present.

The inarticulate Crania Californica Berry 1921 (Fam. Craniidae) was encountered in the northern fjords where it cemented to the walls by the brachial valve (Fig. 2b). It was most abundant on sloping surfaces $\left(<90^{\circ}\right)$ where few other organisms were present. It is a distinctive brachiopod but may be obscured by algal or bryozoan growths.

Other brachiopod species are known in these waters but were never found in collections nor positively identified in photographs. Hemithyris psittacea (Gmelin 1790 ) is distinguished by its black coloration and Frieleia halli Dall 1894 by its small size. Both may have been misidentified as $L$. californianus although we believe this unlikely. Terebratalia transversa (Sowerby 1846 ), so common in water $<50 \mathrm{~m}$, was never seen. The smallest brachiopods from photographs are hard to identify and thus other species may have been missed.

\section{Brachiopod distribution in mainland fjords}

Laqueus californianus was the most abundant brachiopod species in Jervis, Knight and Dean/Burke and numbers were comparable between fjords (Fig. 3). Differences in physico-chemical characteristics of these fjords were not reflected in densities. This species was uncommon in the shallow subtidal and its abundance decreased above $120 \mathrm{~m}$. L. californianus was seen in water with very high suspended sediment loads at the head of Knight Inlet where a sponge and a coral were the only other persistent epifauna. It was found also in high current areas such as the sills of Burke and Knight Inlets. Terebratulina unguicula was rarely seen in Jervis Inlet. In Knight Inlet it was abundant only in the upper $100 \mathrm{~m}$ where turbulent tidal action near the sill was pronounced. The occurrence of $T$. unguicula in low numbers near the bottom of Dean/Burke Channel (Fig. 3 ) indicates that this species is not limited to shallow water.

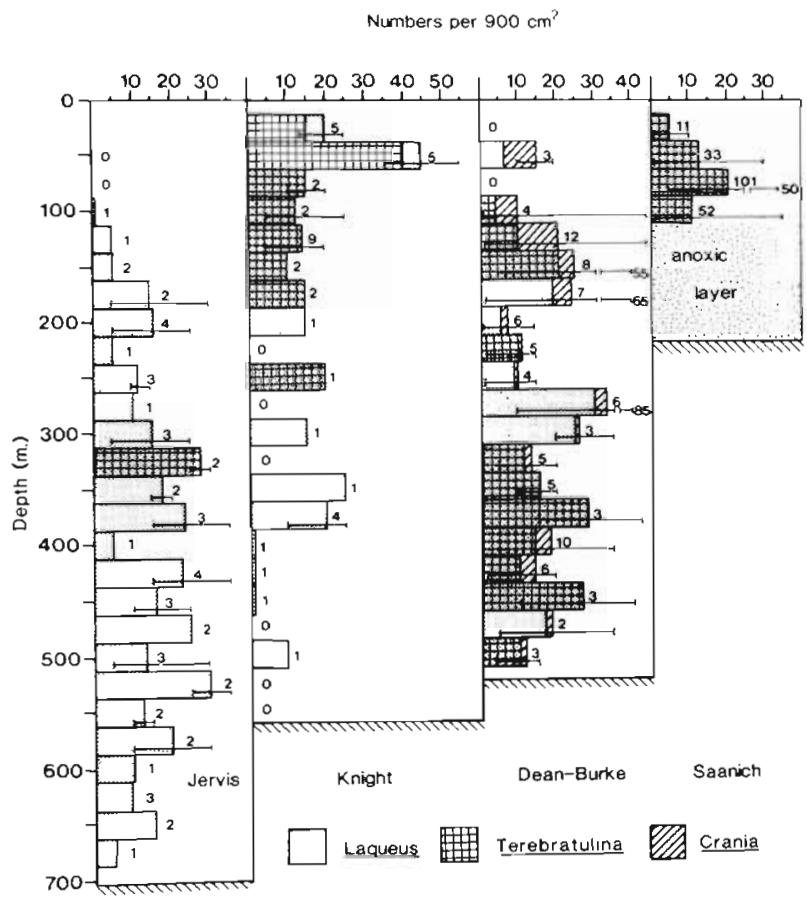

Fig. 3. Densities of brachiopods in 4 inlets. Counts were made in a 30 by $30 \mathrm{~cm}$ area. Laqueus californianus was much the commonest species in the mainland fjords but two-species counts are recorded if any Terebratulina unguicula were seen. Crania californica was recorded only in Dean/Burke where they were counted separately. Photographs in $25 \mathrm{~m}$ depth intervals were pooled as replicates, the number of which is recorded beside each observation. The bars represent the ranges of counts made

Crania californica was found throughout Dean/ Burke Channels but was most common above $200 \mathrm{~m}$. In some areas, the sloping surface and dense cover by this inarticulate made counts impossible. Dives in other coastal fjords confirmed the ubiquitous presence of Laqueus californianus, the spotty presence of Terebratulina unguicula that is more common in water $<200 \mathrm{~m}$, and the absence of $C$. californica in southern mainland British Columbia fjords. 


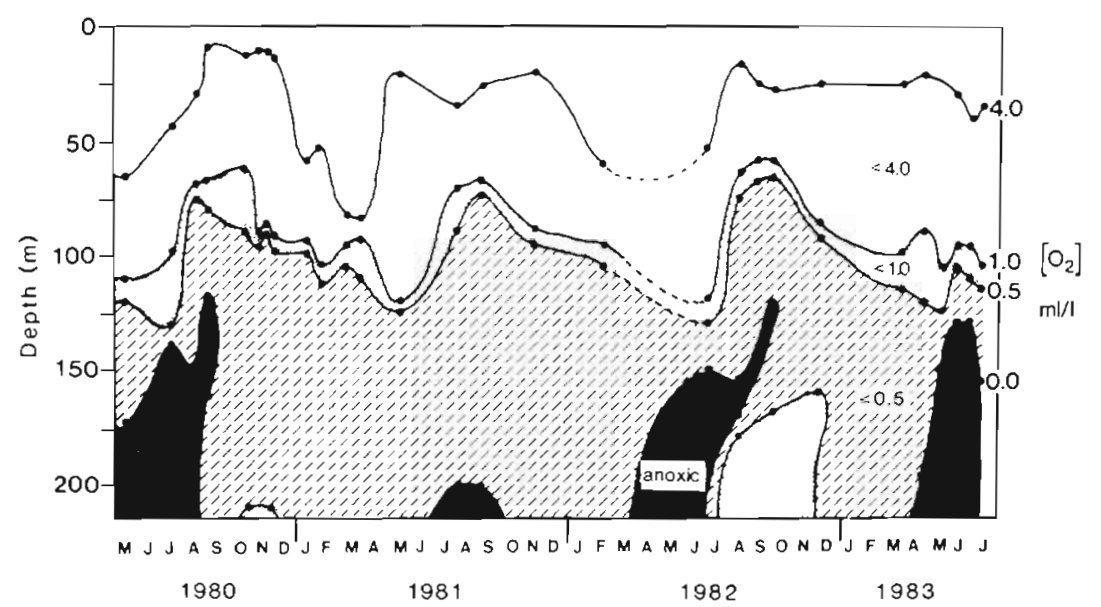

Fig. 4. Oxygen concentrations at one site in Saanich Inlet from 1980 to 1983 . Lines are those of equal concentrations; darkest shading represents anoxic water; dots are interpolations from each sample profile. Inflow of dense oxygenated water displaced low oxygen water upward each year $\left(1 \mathrm{ml} \mathrm{l}^{-1} \mathrm{O}_{2}=\right.$ $1.42 \mathrm{mg} \mathrm{l}^{-1}=1.42 \mathrm{ppm} \mathrm{O}_{2}$ ). Most data collected by authors: supplementary data from Burd \& Brinkhurst (1984) and Juniper \& Brinkhurst (1986)

\section{Dissolved oxygen patterns}

There was no evidence of low oxygen stress in the mainland fjords studied. In Jervis, Lazier (1963) recorded an oxygen minimum layer of $2.0 \mathrm{ml}^{-1}$ at about $230 \mathrm{~m}$ and our profiles never recorded a value lower than $2.7 \mathrm{ml} \mathrm{l}^{-1}$. Knight Inlet dissolved oxygen in 7 profiles rarely fell below $3.8 \mathrm{ml} \mathrm{l}^{-1}$ while Burke Channel levels were $2.7 \mathrm{ml} \mathrm{l}^{-1}$ at the bottom.

The annual development of hypoxic to anoxic water in Saanich Inlet was very pronounced. The deep-water renewal phenomenon in September-October of each year is evident on Fig. 4 as low oxygen water is displaced by inflowing water. Anoxia in the bottom waters did not develop extensively in 1981 but in 1980 and 1982 (Fig. 4) and 1983 (from data taken at a different site in the inlet) the anoxic water pushed into the zone above $130 \mathrm{~m}$ where epifauna inhabited the cliffs. From the submersible, the anoxic interface appeared very murky and pronounced.

\section{Saanich brachiopod distribution patterns}

The reduced water clarity of Saanich, the dense epifaunal community, and the small size of Terebratulina unguicula resulted in enough difficulties in distinguishing species that density counts were not separated. Laqueus californianus and $T$. unguicula occurred in roughly equal numbers and highest combined numbers are 450 to $550 \mathrm{~m}^{-2}$ between 65 and $90 \mathrm{~m}$ depth (Fig. 5). Ranges and habitats of the 2 species overlapped except that $T$ unguicula was found deeper. It was the most abundant species below $80 \mathrm{~m}$ where, at the base of its range, oxygen concentrations frequently fell to between 0.1 and $0.2 \mathrm{ml} \mathrm{l}^{-1}$. Both species were sighted in the talus common at $30 \mathrm{~m}$. Many of the abundance variations seen on successive dates on
Fig. 5 can be attributed to the heterogeneous nature of the habitat and uneven dispersion of brachiopods. The last 3 observation sets were made on the chain transect and show more consistency. There was no obvious mass recruitment to the cliff community evident either in the data or in visual inspection from the submersible.

The brachiopod range has contracted since 1980 as the deepest occurrence moved steadily upward. This photographic observation was corroborated by submersible sightings (Fig. 5). In addition, the numbers of the 2 species in the 93 to $97 \mathrm{~m}$ depth interval decreased. Quadrat densities in 1980 and 1981 at this depth were significantly higher ( $t$-test, $p<0.01$ ) than 1982 through 1984. Notes from a May 1980 dive recorded brachiopods at $110 \mathrm{~m}$ but the anoxic rise in late September severely depleted all the epibenthic community. In November 1980, numerous brachiopod shells were seen on ledges at $105 \mathrm{~m}$ and decaying tissues of anemones, sponges and ascidians dotted the cliff. Similar observations were made in September 1982. No recruitment to this zone has since occurred; a dive in 1986 recorded only a few brachiopods as low as $95 \mathrm{~m}$.

The accumulated shell grab in 1982 ('death assemblage') consisted of 693 shells none of which had tissue. One-quarter (165) was Terebratulina unguicula and the remainder was Laqueus californianus. Degree of articulation was moderate $(40 \%)$ and dissolution of some shells was advanced. This ledge would have accumulated several mortality events and the lowered $\mathrm{pH}$ of the hypoxic water (down to 7.2; J P Tully unpubl. 1931) would enhance dissolution.

\section{Brachiopod size distributions}

Photographic measurements of Laqueus californianus from Jervis, Knight and Dean/Burke gave near- 


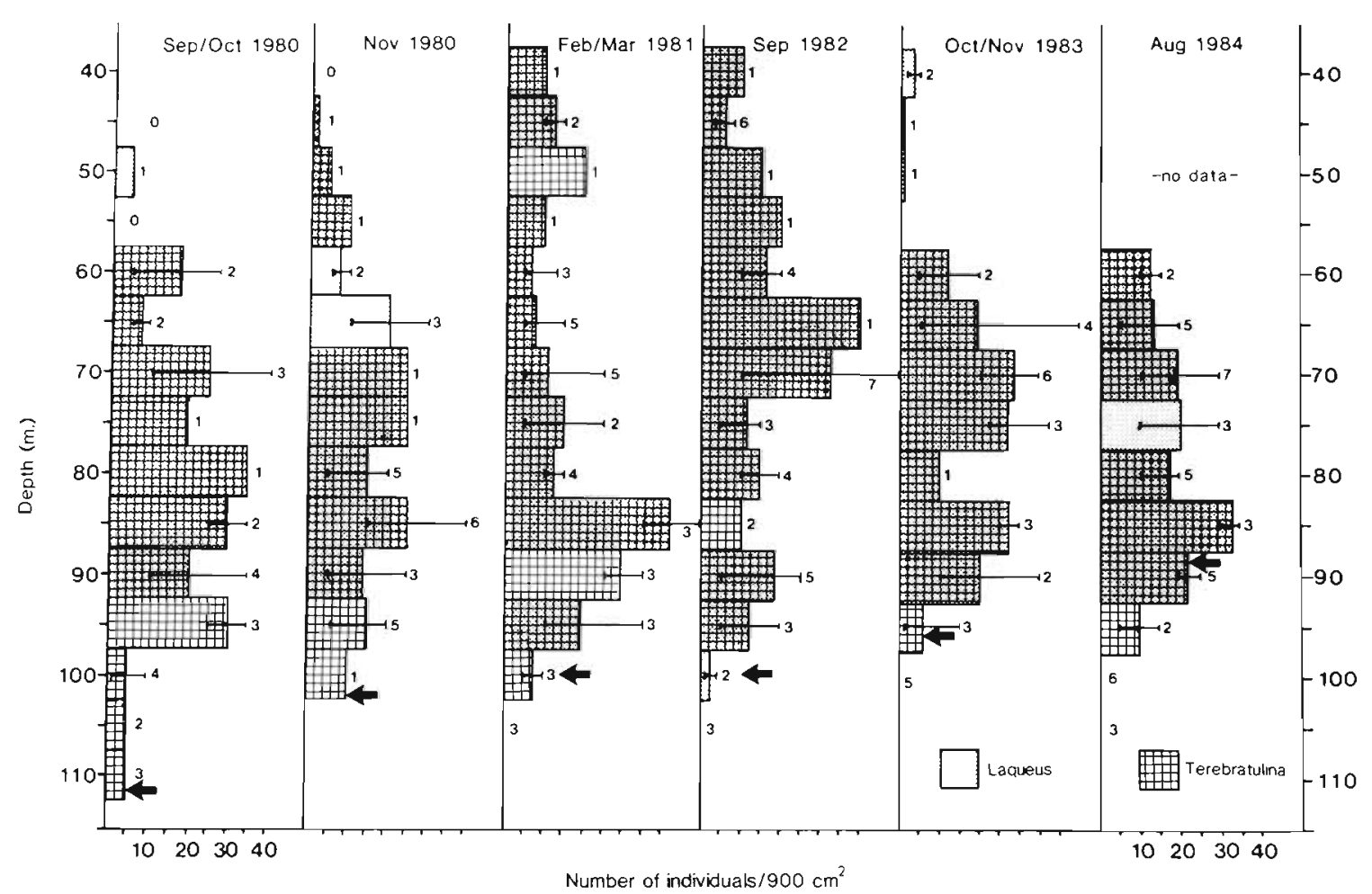

Fig. 5. Distributions of brachiopod populations in Saanich Inlet at the same site over 4 yr. Densities: numbers $900 \mathrm{~cm}^{-2}$ rounded to the nearest 5 for each replicate. Each block shows the number of replicates used and the range of values observed. The deepest sighting of a brachiopod by submersible observers during the dive series of that date is indicated by an arrow

normal size distributions (Fig. 6A, C, D). Size ranges in all fjords were similar; maximum width measurement was $31 \mathrm{~mm}$. Jervis photographs were very consistent as each sample echoed the whole distribution while Knight and Dean/Burke showed more heterogeneous clumping of the size classes. In no inlet was there a consistent size relationship with depth. Compared to the other fjords, the $L$. Californianus distribution from Dean/Burke showed a significant shift to the larger sizes (Kolmogorov-Smirnov, $p<0.05$ ) but the differences were not outstanding (Fig. 6)

Size distribution of the Jervis dredged specimens (Fig. 6B) did not reflect photographed sizes (Fig. 6A). Most dredged specimens were attached to glass sponge (Aphrocallistes vastus) skeletons while the photographed brachiopods were attached directly to the cliff walls. Fig. $6 \mathrm{~B}$ may be a representation of sponge disintegration rate; a few sponge bases become indurated enough to support the full life-span of these brachiopods.

In Saanich Inlet, the photographed size distribution was bimodal (Fig. 7A), a feature probably due to the presence of 2 species. The death assemblage showed the same shape when the 2 species are combined, although the representation by Laqueus californianus was quite variable. Live Terebratulina unguicula measured from collected specimens in Saanich Inlet were significantly smaller than collected $L$. californianus (Table 1) ( $t$-test, $p<0.001$ ); the 2 species differed in the death assemblage in a similar fashion ( $t$-test, $p<0.001)$. The distribution in Fig. $7 \mathrm{~B}$ is shifted to the left of Fig. 7A. This difference between life and death assemblages may be due to: (1) better discernment of smaller sizes with specimens in hand; (2) magnification of sizes in photographs; or (3) the mortality event 'sampling' the smaller sizes. Magnification did not occur in the size ranges photographed and dredged in Jervis. The last possibility seems most likely as the dead shells probably accumulated from hypoxic deaths in the lower part of the inlet. There is a significant difference in distribution of sizes in the 2 brachiopod populations above and below $80 \mathrm{~m}$ (Table 1 ; and Kolmogorov-Smirnoff test, $p<0.05$ ). No significant differences were found in size distributions before and after 1982.

The Terebratulina unguicula sizes measured from live and dead collected specimens in Saanich Inlet (Table 1) were very small. $T$. unguicula from the shallow parts of Knight Inlet (Fig. 3) had an average size twice that of the Saanich population. 


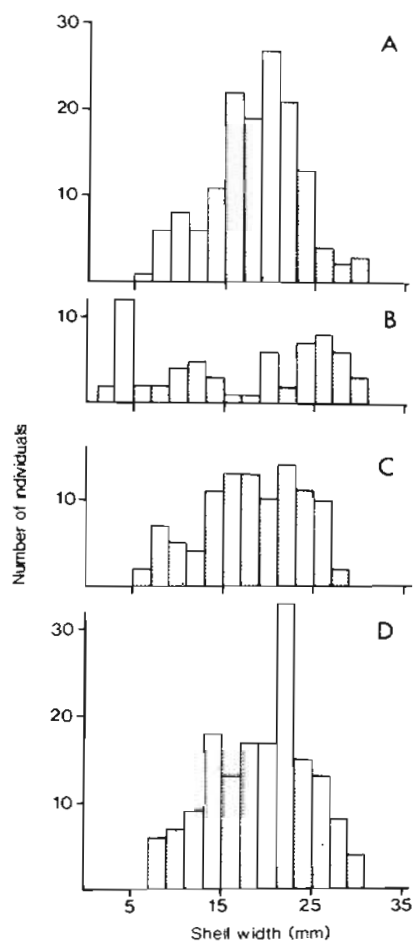

Fig. 6. Laqueus californianus. Size-frequency distributions. (A) Jervis Inlet photographed individuals; (B) Jervis Inlet dredged individuals; (C) Knight Inlet photographed individuals; (D) Dean/Burke Channel photographed individuals

\section{Other observations}

Laqueus californianus surfaces were often free of fouling but epifauna did occur, especially in areas of low space availability (Fig. 2D). Competition for space was probably a limiting factor in some areas of Saanich where both brachiopod species were more heavily fouled. In Knight Inlet, high current areas that showed a dramatic increase in serpulid and sponge densities (Farrow et al. 1983) decreased somewhat in brachiopod densities ( 75 to $150 \mathrm{~m}$ in Fig. 3).

\section{DISCUSSION}

\section{Photographic methods}

This study was initiated to examine the efficacy of the photographic method for benthic community assessment. Although we are confident of the results presented, accuracy was limited by the photographs. Of the total number of pictures taken, about $20 \%$ were good enough for density counts and only $3 \%$ were used for size measurements. Unsuitable substratum and submersible positioning accounted for many unus-

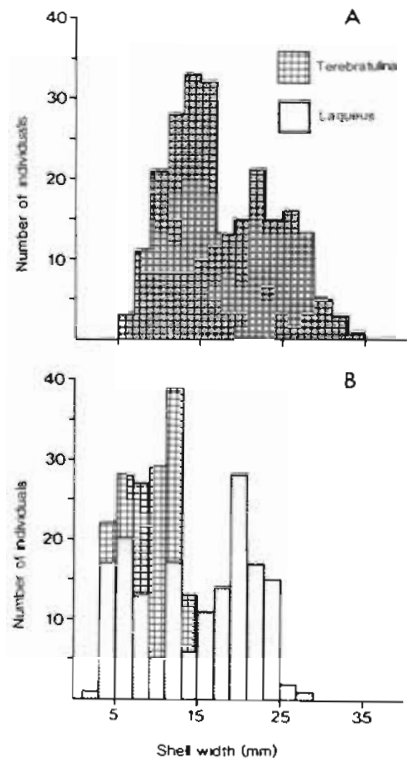

Fig. 7. Saanich Inlet brachiopod sizes. (A) Live specimen widths as measured in photographs; species were not discriminated. $(B)$ 'Death assemblage' individuals separated into the 2 species

Table 1. Mean brachiopod widths $(\mathrm{mm})$ for populations in different fjords. $s=$ standard deviation, $n=$ sample size

\begin{tabular}{|c|c|c|c|}
\hline & $\bar{x}$ & $s$ & $n$ \\
\hline \multicolumn{4}{|l|}{ Laqueus californianus } \\
\hline \multicolumn{4}{|l|}{ Saanich Inlet } \\
\hline live specimens & 19.56 & 7.55 & 20 \\
\hline death assemblage & 14.53 & 6.96 & 167 \\
\hline \multicolumn{4}{|l|}{ Jervis Inlet } \\
\hline photographs in situ & 18.26 & 5.63 & 144 \\
\hline live specimens & 16.34 & 9.41 & 63 \\
\hline \multicolumn{4}{|l|}{ Knight Inlet } \\
\hline photographs in situ & 18.21 & 5.63 & 102 \\
\hline \multicolumn{4}{|l|}{ Dean/Burke Inlets } \\
\hline photographs in situ & 20.32 & 5.10 & 161 \\
\hline \multicolumn{4}{|l|}{ Terebratulina unguicula } \\
\hline live specimens & 7.92 & 3.14 & Saanich Inlet \\
\hline death assemblage & 9.74 & 2.60 & 80 \\
\hline \multicolumn{4}{|l|}{ Knight Inlet ${ }^{a}$} \\
\hline photograph in situ & 19.31 & 4.70 & 32 \\
\hline \multicolumn{4}{|l|}{ Both species ${ }^{b}$} \\
\hline \multicolumn{4}{|l|}{ Saanich Inlet } \\
\hline photographs in situ & 17.55 & 6.45 & 231 \\
\hline photographs $>80 \mathrm{~m}$ & 14.80 & 4.56 & 116 \\
\hline photographs $<80 \mathrm{~m}$ & 20.31 & 6.89 & 115 \\
\hline \multicolumn{4}{|c|}{$\begin{array}{l}\text { "One clear photograph with scale and only Terebratulina } \\
\text { at } 40 \text { m depth } \\
\text { b Confidence in distinguishing the species of every speci- } \\
\text { men in Saanich was not high enough to allow separation } \\
\text { of the entire sample }\end{array}$} \\
\hline
\end{tabular}


able pictures, but poor resolution was usually the problem. We found that eyes gave the best resolution, handheld cameras with Kodachrome 64 film gave good focus and colour, while the external camera with Ektachrome 64 film was usually better placed. Since this study, the use of Vericolor III negative film (available in 100' rolls) gives fine resolution for the external camera but one must use prints. It is little wonder that there is a dearth of information on deep-water communities - the work is difficult and expensive.

\section{Brachiopod habitats}

Little information is available on the ecology of Laqueus californianus; Bernard (1972) cited a depth range to $494 \mathrm{~m}$, and Zezina (1973) recorded densities of $25 \mathrm{~m}^{-2}$ in the Gulf of Alaska. We find this brachiopod is the most common species on the western Canadian coast appearing from intertidal to the bottom of the deepest fjord $(700 \mathrm{~m})$. The highest quadrat count made was $945 \mathrm{~m}^{-2}$, although some poorly photographed areas appeared to have higher densities. $L$. californianus was very tolerant to varying conditions of turbidity, turbulence and oxygen concentration.

Terebratulina unguicula, found by Bernard (1972) down to $858 \mathrm{~m}$ depth, has an irregular distribution. It is abundant in the San Juan Islands where Thayer (1975) sampled several populations, but the high numbers there and in Saanich Inlet were not reflected in the coastal fjords. The exception was one high density measurement in Knight Inlet of $610 \mathrm{~m}^{-2}$. Zezina (1973) found this species to be a consistent component of dredge hauls along the Alaskan coast. It did not appear as tolerant as Laqueus californianus of high suspended sediment loads, but extended deeper into the low oxygen levels of Saanich Inlet. As described for a congeneric, T. septentrionalis (Witman \& Cooper 1983), it was more common on vertical and overhanging than sloping surfaces.

Crania californica had been rarely observed because it is nearly impossible to dredge. The species is recorded in the Barkley Sound area (Austin 1985) although we find it only in the northern fjords between 35 and $510 \mathrm{~m}$ depth and conservatively estimate densities to $500 \mathrm{~m}^{-2}$. It showed a marked preference for sloping and often sedimented surfaces even in the photic zone. C. anomala larvae settle at an early developmental stage but planktonic stages are unknown (Rowell 1960). The absence of abundant Crania and Terebratulina in the coastal fjords opening off the Strait of Georgia suggests that larval dispersion into these waters is constrained by restricted water circulation. Other community components similarly suggest a restriction.

\section{Brachiopod community}

Figs. 3 and 5 demonstrate the consistency of brachiopod contribution to this fjord fauna: they are ubiquitous and persistent. Numerically they are equivalent to other dominating species (own unpubl. obs.). The numbers here are not unusual when compared to other brachiopod studies where densities as high as $20000 \mathrm{~m}^{-2}$ have been found (Doherty 1979) although other studies are generally restricted to small areal extents at depths shallower than $40 \mathrm{~m}$. Brachiopods form a major part of the west coast fjord benthos; in 379 photographic observations from 30 to $700 \mathrm{~m}$ depth the average density of brachiopods was $192.2 \mathrm{~m}^{-2}$ ( $\mathrm{s}=$ 137.8).

Many filter- and suspension-feeding taxa are represented on these fjord walls where available space can drop below $20 \%$ (Farrow et al. 1983, Levings et al. 1983). Only in the most crowded conditions do brachiopods appear competitively inferior: they can be overgrown by sponges and serpulids. Even in highdensity conditions, settlement of juveniles on adults is rare although settlement on other organisms is observed. Predation was difficult to document although asteroids were seen draped over Laqueus californianus. Thayer (1985) reported that predators find brachiopods 'distasteful' and $L$. californianus is the least preferred prey.

Many taxa encountered also have long geological records (corals, hexactinellid sponges, serpulid polychaetes) but their abundance or habitat span was not as great as the brachiopods. Yet one does not find reference to these animals as 'minor' or 'declining' taxa, perhaps because of their abundance in accessible tropical habitats. One group that was rarely encountered was Bivalvia - apart from the occasional scallop and mussel. It is often stated that brachiopods were replaced by bivalves because of direct or indirect competition, superior design, or differing evolutionary potential for niche exploitation (Rudwick 1970, Stanley 1974, Thayer 1975, 1986a, Steele-Petrovic 1979, Valentine \& Jablonski 1983). But this subtidal hard-substratum coastal habitat is still the domain of the brachiopod with almost no intrusion by bivalves. Such outcrop is not easily accessible but it represents a large proportion of shorelines on many continents and islands.

\section{Tolerance of marginal conditions}

The high suspended sediment load in many mainland fjords that drain glacier fields is a major deterrent to most of the suspension-feeding animals but appears to affect Laqueus californianus the least (Farrow et al. 1983). The highest numbers of Crania californica occur 
on sloping surfaces where sediments can accumulate. Richardson (1981a) described modern brachiopods free-living in mud similar to many Paleozoic forms. The basis for sediment tolerance was explairied by SteelePetrovic (1975) and Thayer (1986a) who examined the efficiency of the lophophore handling and sedimentrejection mechanism. High turbidity does not limit these animals either in theory or in practice.

Some of the highest densities we measured in Saanich Inlet were below $80 \mathrm{~m}$, the depth below which oxygen fluctuations are marked (Tunnicliffe 1981). Abundance of invertebrates in this zone corresponds to food abundance; Devol (1981) using nets and Mackie \& Mills (1983) using a submersible recorded very high densities of zooplankton concentrated at the oxycline. High primary production by microbial oxidation of reduced compounds at the anoxic interface is a likely cause of these densities (Mackie \& Mills 1983, Juniper \& Brinkhurst 1986). Yet for $30 \%$ of the time monitored there, oxygen concentrations were less than $1.0 \mathrm{ml} \mathrm{l}^{-1}$ and Juniper \& Brinkhurst (1986) reported that this low oxygen water may have some hydrogen sulphide. Davis (1975) showed that survival of aquatic invertebrates in protracted low oxygen conditions depends upon their ability to (1) produce energy anaerobically, or (2) extract oxygen from low water concentrations. Brachiopods appear capable of both. Terebratulina septentrionalis can respire anaerobically and survive anoxia for 3.5 d (Hammen 1977) while Shumway (1982) and Thayer (1986b) showed that articulates maintain a high degree of independence of respiration rate on oxygen concentration. The latter authors suggested that shell punctae (small pores) may aid oxygen uptake and allow long periods of shell closure. In a cursory scanning electron microscope examination of Laqueus californianus shells from Saanich and Jervis, we could see no difference in punctae size or pattern in response to low oxygen levels. The very low metabolic rate of brachiopods serves to reduce the oxygen demand (Hammen et al. 1962, Shumway 1982) as does low-cost laminar flows within the shell which makes them very energy efficient (LaBarbera 1981). Finally, the abilities of both $L$. californianus and $T$ unguicula to reorient the shell in response to water flow (LaBarbera 1977) may increase total oxygen flux.

The brachiopods must have a considerable ability to extract available oxygen and tolerate accumulating hydrogen sulphide. The greater abundance and lower occurrence of Terebratulina unguicula compared to Laqueus californianus suggests a differential ability. The accumulated brachiopod debris revealed no age specific mortality but the high proportion of $L$. californianus shells despite more abundant deep $T$. unguicula suggests that it is less tolerant of hypoxia. Animals found near $100 \mathrm{~m}$ in Saanich Inlet number only about 7 species including Porifera, Coelenterata, Ascidiacea and Brachiopoda. Devol (1981) felt that the oxygen fluctuations here preclude any metabolic acclimation by Saanich animals. The anoxic event of 1980 affected many species (Tunnicliffe 1981) and there has been a retreat of the basal limit of the community ever since. It seems as if conditions in Saanich Inlet are steadily deteriorating but there may be a longer-period cycle in effect here.

Low oxygen conditions as evidenced by black shales in the fossil record may have caused local brachiopod extinctions (Rudwick 1970, Hallam 1987), but survival of brachiopods in places such as Saanich Inlet should be considered before concluding that hypoxia kills. Observations of brachiopods in black shales need not elicit the assumption that they have 'rafted in' (Bergström 1968, Thayer 1974).

The size class profile of an invertebrate population depends upon recruit abundance, size-specific mortality, larval success and growth rate. Doherty (1979) demonstrated with his own, and past work that brachiopod growth rates are not linear as they decrease in later life and that, although recruit peaks can be identified, populations are not always right-skewed (juvenile dominated). Our photographic study cannot identify individuals below $0.5 \mathrm{~cm}$ so we may miss a juvenile peak. We tend to find normal to left-skewed populations in these fjords. It is interesting to note that our Jervis dredge sample of Laqueus californianus (Fig. $6 \mathrm{~B}$ ) is nearly identical to a sample dredged by Thayer (1975) in Washington. Because the live population looks so different (Fig. 6A) we would caution against much faith in dredge results.

These brachiopods probably have an age range up to $10 \mathrm{yr}$ (Paine 1969). The small size of the Saanich Terebratulina unguicula may indicate young individuals, but in $5 \mathrm{yr}$ of diving, we never saw any large $T$ unguicula either alive or dead. As Thayer (1975) found specimens up to $22 \mathrm{~mm}$ in length only a few miles away, the small Saanich sizes (maximum length $16 \mathrm{~mm}$ ) may well be a function of habitat that induces stunted forms. T. unguicula larvae are brooded then have a short-lived free-swimming stage (Long 1969). Their patchy distribution in British Columbia both on long and short distance scales suggests poor dissemination. Settlement of larvae near parents has been demonstrated for other brooding brachipods (Logan \& Noble 1971, Doherty 1979). In Comparison, Laqueus californianus populations are wide-spread and homogeneous. Larval development is unknown but it would be non-planktotrophic, as are all Recent articulates (Rudwick 1970, Valentine \& Jablonski 1983). However, a relatively longer planktic period would contribute to its wider distribution.

Many publications have examined modern 
brachiopod populations for the sake of contributing to the interpretation of past assemblages (Percival 1944. Paine 1969, Logan \& Noble 1971, McCammon 1973, Logan 1975, Thayer 1975, Doherty 1979, Stewart 1981, Witman \& Cooper 1983). Work in New Zealand fjords (Grange et al. 1981, Richardson 1981b) and the Mediterranean (Emig 1987) illustrated that dominance by brachiopods is not unique to British Columbia. These and other studies prove the large contribution of this phylum to many modern assemblages. The success of the Brachiopoda in Paleozoic communities has cast a large shadow over the modern role of this phylum. But they have kept more than just a toe-hold in the Recent - many subtidal hard-substratum habitats, where bivalves are nowhere to be found, remain the domain of the brachiopod.

Acknowledgements. Without the skill and forbearance of the 'Pisces IV' pilots this work would not have been possible. We thank Mr Pat Shaw for initial work on this project and Dr W. Austin for help in the field. A. Fischer drafted the figures and D. McHugh made helpful comments on the manuscript. Funding was provided by NSERC Canada and ship-time made available by Fisheries and Oceans, Canada.

\section{LITERATURE CITED}

Anderson, J. J., Devol, A. H. (1973). Deep water renewal in Saanich Inlet, an intermittently anoxic basin. Estuar. coast. mar. Sci. 1: 10

Austin, W. C. (1985). An annotated checklist of marine invertebrates in the cold temperate northeast Pacific (3 vols.). Khoyatan Marine Laboratory, Cowichan Bay, British Columbia

Bergström, J. (1968). Some Ordovician and Silurian brachiopod assemblages. Lethaia 1: 230-237

Bernard, F. R. (1972). The living Brachiopoda of British Columbia. Syesis 5: 73-82

Burd, B. J., Brinkhurst, R. O. (1984). The distribution of the galatheid crab Munida quadrispina (Benedict 1902) in relation to oxygen concentrations in British Columbia's fjords. J. exp. mar. Biol. Ecol. 81: 1-20

Dall, W. H. (1920). Annotated list of the Recent Brachiopoda in the collection of the United States National Museum. Proc. U. S. natn. Mus. 57 211-377

Davidson, T. (1887). Monograph of Recent Brachiopoda. Trans. Linn. Soc. London (Ser. 2 i Volume 4, Part 2)

Davis, J. C. (1975). Minimal dissolved oxygen requirements of aquatic life with emphasis on Canadian species: a review. J. Fish. Res. Bd Can. 32: 2295-2332

Devol, A. H. (1981). Vertical distribution of zooplankton respiration in relation to the intense oxygen minimum zones in two British Columbia fjords. J. Plankton Res. 3: 593-602

Doherty, P. J. (1979). A demographic study of a subtidal population of the New Zealand articulate brachiopod Terebratella inconspicua. Mar. Biol. 52: 331-342

Emig, C. C. (1987). Offshore brachiopods investigated by submersible. J. exp. mar. Biol. Ecol. 108: 261-273

Farmer, D. M., Smith, J. D. (1980). Tidal interaction of stratified flow with a sill in Knight Inlet. Deep Sea Res. 27: 239-254

Farrow, G. E., Syvitski, J. P. M., Tunnicliffe, V (1983). Suspended particulate loading on the macrobenthos in a highly turbid fjord: Knight Inlet, British Columbia. Can. J. Fish. Aquat. Sci. 40: 273-288

Grange, K. R., Singleton, R. J., Richardson, J. R., Hill, P. J., Main, W. (1981). Shallow rock-wall biological associations of some southern fjords of New Zealand. N. Z. J. Zool. 8 : 209-227

Hallam, A. (1987). Radiations and extinctions in relation to environmental change in the marine Lower Jurassic of northwest Europe. Paleobiol. 13: 152-168

Hammen, C. S. (1977). Brachiopod metabolism and enzymes Am. Zool. 17. 141-147

Hammen, C. S., Hanlon, D. P., Lum, S. (1962). Oxidative metabolism of Lingula. Comp. Biochem. Physiol. 5: 185-191

Hertlein, L. G., Grant, U. S. (1944). The Cenozoic Brachiopoda of western North America. Publ. Univ. Calif. Math. Phys. Sci. 3: $1-236$

Herlinveaux, R. H. (1962). Oceanography of Saanich Inlet in Vancouver Island, British Columbia. J. Fish. Res. Bd Can. 19: $1-37$

Juniper, S. K., Brinkhurst, R. O. (1986). Water-column dark $\mathrm{CO}_{2}$ fixation and bacterial-mat growth in intermittently anoxic Saanich Inlet, British Columbia. Mar Ecol. Prog. Ser, 33: 41-50

LaBarbera, M. (1977). Brachiopod orientation to water movement. 1. Theory, laboratory behavior, and field orientations. Paleobiology 3: 270-287

LaBarbera, M. (1981). Water flow patterns in and around three species of articulate brachiopods. J. exp. mar. Biol. Ecol. 55: $185-206$

Lazier, J. R. N. (1963). Some aspects of the oceanographic structure of the Jervis Inlet system. M. Sc. thesis, Institute of Oceanography, University of British Columbia, Vancouver, British Columbia

Levings, C. D., Foreman, R. E., Tunnicliffe, V (1983). Review of the benthos of the Strait of Georgia and contiguous fjords. Can. J. Fish. Aquat. Sci. 40: 1120-1141

Logan, A. (1975). Ecological observations on the Recent articulate brachiopod Argyrotheca bermudana Dall from the Bermuda platform. Bull, mar. Sci. 25: 186-204

Logan, A., Noble, J. P. A. (1971). A Recent shallow-water community from the Bay of Fundy. Marit. Sediments 7 : $85-91$

Long, J. A. (1964). The embryology of three species representing three superfamilies of articulate Brachiopoda. Doctoral Diss., University of Washington, Seattle

Mackie, G. O., Mills, C. E. (1983). Use of the Pisces IV submersible for zooplankton studies in coastal waters of British Columbia. Can. J. Fish. Aquat. Sci. 40: 763-776

Mattox, N. T. (1955). Observations on the brachiopod communities near Santa Catalina Island. In: Allan Hancock Foundation for Scientific Research. Essays in the natural sciences in honor of Captain Allan Hancock. Univ. Southern California Press, Los Angeles, p. 73-83

McCammon, H. M (1973). The ecology of Magellania venosa, an articulate brachiopod. J. Paleontol. 47: 266-278

Paine, R. T (1969). Growth and size distribution of the brachiopod Terebratalia transversa Sowerby. Pacif. Sci. 23: $337-343$

Percival, E. (1944). A contribution to the life-history of the brachiopod, Terebratella inconspicua Sowerby. Trans. R Soc. N. Z. 74: 1-23

Richardson, J. R. (1981a). Brachiopods in mud: resolution of a dilemma. Science 211. 1161-1163

Richardson, J. R. (1981b). Distribution and orientation of six articulate brachiopod species from New Zealand. N. Z. J. Zool. 8: 189-196 
Rowell, A. J. (1960). Some early stages in the development of the brachiopod Crania anomola (Muller). Ann. Mag. Nat. Hist. 3: 35-52

Rudwick, M. J. S. (1970). Living and fossil brachiopods. Hutchinson and Co., London

Shumway, S. E. (1982). Oxygen consumption in brachiopods and the possible role of punctae. J. exp. mar. Biol. Ecol. 58: $207-220$

Stanley, S. M. (1974). What has happened to the articulate brachiopods? Geol. Soc. Am. Abstr. Ann. Meetings, Miami Beach, Florida, p. 966-967

Steele-Petrovic, H. M. (1975). An explanation for the tolerance of brachiopods and relative intolerance of filterfeeding bivalves for soft muddy bottoms. J. Paleontol. 49: $552-556$

Steele-Petrovic, H. M. (1979). The physiological differences between articulate brachiopods and filter-feeding bivalves as a factor in the evolution of marine level-bottom communities. Palaeontol. J. 22: 101-134

Stewart, I. R. (1981). Population structure of articulate brachiopod species from soft and hard substrates. N.Z. Zool. 8: 197-207

Strickland, J. D. H., Parsons, T R. (1972). A practical handbook of seawater analysis, 2nd edn. Bull. Fish. Res. Bd Can. 167

Thayer, C. W. (1974). Marine paleoecology in the Upper Devonian of New York. Lethaia 7: 121-155
Thayer, C. W. (1975). Size-frequency and population structure of brachiopods. Palaeogeogr. Palaeoclimatol. Palaeoecol. 17: $139-148$

Thayer, C. W. (1979). Biological bulldozers and the evolution of marine benthic communities. Science 203: 458-461

Thayer, C. W (1985). Brachiopods versus mussels: competition, predation, and palatability. Science 228: 1527-1528

Thayer, C. W. (1986a). Are brachiopods better than bivalves? Mechanisms of turbidity tolerance and their interaction with feeding in articulates. Paleobiology 12: 161-174

Thayer, C. W. (1986b). Respiration and function of brachiopod punctae. Lethaia 19: 23-31

Tunnicliffe, V. (1981). High species diversity and abundance of the epibenthic community in an oxygen-deficient basin. Nature, Lond. 294: 354-356

Valentine, J. W., Jablonski, D. (1983). Larval adaptations and patterns of brachiopod diversity in space and time. Evolution 37: 1052-1061

Witman, J. D., Cooper, R. A. (1983). Disturbance and contrasting patterns of population structure in the brachiopod Terebratulina septentrionalis (Couthouy) from two subtidal habitats. J. exp. mar. Biol. Ecol. 73: 57-79

Zezina, O. N. (1973). Composition and distribution of brachiopods among the benthos of the Gulf of Alaska. In: Filatova, Z. A. (ed.) Multidisciplinary investigations of the continental slope in the Gulf of Alaska area. Trudy Inst. Okeanol., Akad. nauk SSSR. (Russian)

This article was submitted to the editor; it was accepted for printing on May 14, 1988 